\title{
The Development of Foundational and New Literacies with Digital Tools Across the European Higher Education Area
}

\section{Lee McCallum}

University of Exeter. Graduate School of Education

mail: L.McCallum2dexeter.ac.uk

ORCID: https://orcid.org/0000-0001-9873-6451

\begin{abstract}
The $21^{\text {st }}$ century EFL writing classroom is currently undergoing a substantial change in character. The classroom continues to transform from one that focuses on the building blocks of being able to write to one that is characterised by a view that writing is digitally-informed and led. This paper synthesises research that documents the perceived gains of using digital tools to, on the one hand, improve students' foundational literacies in English writing, and on the other hand, to develop 'new' digitally oriented literacies that exist and arise from the use of these tools. The focus of the synthesis is on member countries that are included in the European Higher Education Area (EHEA) initiative. The paper presents a systematic review of studies in international and local journals from 2000-2020. The review provides an overview of the foci of the studies, the types of writing, tasks and technologies being used, the approaches taken to evaluate and provide feedback on students' writing, and the influence digital literacies may have on fostering these foundational literacies. The paper concludes by considering gaps in the EHEA landscape and offers recommendations for further development.
\end{abstract}

Keywords: foundational literacies; new literacies; digital tools; EHEA; writing proficiency.

\section{El desarrollo de nuevas habilidades fundamentales mediante herramientas digitales en el Espacio Europeo de Educación Superior}

\section{RESUMEN}

A día de hoy, el aula de escritura de ESL del siglo XXI está experimentando un cambio sustancial de carácter, pasando de centrarse en los elementos básicos para aprender a escribir a caracterizarse por su visión de que la escritura está informada y dirigida digitalmente. Este artículo sintetiza la investigación que documenta las ganancias percibidas por el uso de herramientas digitales para, por un lado, mejorar las habilidades básicas de los estudiantes en la escritura en inglés y, por otro lado, para desarrollar las "nuevas" habilidades orientadas digitalmente y que surgen del uso de estas herramientas. La síntesis se centra en los países miembro incluidos en la iniciativa del Espacio Europeo de Educación Superior (EEES). El documento presenta una revisión sistemática de los estudios publicados en revistas internacionales y locales entre 2000 y 2020. La revisión proporciona una visión general de los enfoques de los estudios, los tipos de escritura, las tareas y las tecnologías que se utilizan, los enfoques adoptados para evaluar y proporcionar retroalimentación sobre la escritura de los estudiantes, y la influencia que la alfabetización digital puede tener en el fomento de estas habilidades fundamentales. El documento concluye considerando las lagunas en el panorama del EEES y ofrece recomendaciones para un mayor desarrollo.

Palabras clave: habilidades fundamentales; nuevas habilidades; herramientas digitales; EEES; dominio de la escritura.

ISSN: 0210-2773

DOI: https: / /doi.org/10.17811/rifie.50.2.2021.615-624

(c) (i) $\Theta$ Esta obra está bajo una licencia internacional Creative Commons 


\section{Introduction}

Literacy has traditionally been thought of as the ability to read and write. Efforts to develop this competence have traditionally focused on improving learners' decoding and encoding skills. In foreign language learning, this notion of literacy has entailed using the letters and characters of a foreign language alphabet or writing system in line with fixed, rule-governed patterns of use (Elola \& Oskoz, 2017). However, this narrow definition of literacy has been widened considerably over the last twenty years both in mainstream education studies (e.g., Leu et al., 2013) and in second language studies (e.g., Nation \& Macalister, 2021).

In second language studies, literacy has been widened to be considered a plural, multifaceted construct, which, while still concerning traditional notions of reading and writing, has expanded to include other competencies. These competencies broadly align with changes in how text consumption/production has shifted from mere pen and paper to being more digitally informed. Several scholars have unpacked this broad view of literacy (e.g., Cervetti et al., 2006; Knobel \& Lankshear, 2018; Leu et al., 2013). Cervetti et al. (2006) describe how new literacies are generally understood to follow changes in culture, institutions, and mindsets, as well as technologies. Knobel and Lankshear (2018) also make the connection between new literacies and new technologies. They view new literacies as being fused with the use of new technologies that are available for writing and interacting. These concepts of digital literacy and multimodality are fused with theories of new literacies such as computer literacy (the ability to use technology), information literacy (the ability to find and evaluate information), media literacy (critical awareness of media representation and their ideological purposes). Leu et al. (2013) set out a number of guiding features or criteria of new literacies which are fused with new technologies. They see the use of the internet and new technologies requiring new literacies that go beyond traditional reading and writing. They set out how new technologies enable new ways of constructing, shaping, sharing, and accessing content.

These fusions between literacies and technology are particularly important for second language learners. Godwin-Jones (2018) states that much of $21^{\text {st }}$-century writing takes place online, and so this digitalisation means writers need a wide range of skills and genre knowledge to ensure writing is both grammatically correct and in the appropriate register. Nation and Macalister (2021) also tap into the idea that the composition classroom is going through changes as a result of digital advances. They recognise there is now less focus on handwriting and more focus on typing and shifting genres. These new genres comprise blogs, video production, social media writing, podcasts, wikis, and digital fanzines. These genres may complement traditional modes of essay writing and are encouraged to play a more integrated role in writing courses (Nation \& Macalister, 2021). In this respect, they highlight how there is also a change in how readership/ audience is perceived with these different genres requiring students to write for both layperson and specialised audience (e.g., Hafner, 2014).

Nation and Macalister (2021) also comment on how digitalisation has changed the organisation of ideas and deciding which ones take centre stage in a text and which ones can be linked online for readers. A final composition strand relates to the evaluation of digital writing and how feedback is provided, where criteria that evaluate writing in a digital setting need to be recrafted to fit in with this new lens of what composition means. Equally, feedback also needs to blend foundational aspects of writing with those that relate to the use of technology to consider aspects of readership/audience and other aspects of literacy.

This new digital shift has led many scholars to call for a rethink on how second language writing is taught (e.g., Elola \& Oskoz, 2017; Godwin-Jones, 2018). Elola and Oskoz (2017) argue that second language curricula need to be questioned and realigned by evaluating the underpinning definition of literacy that they are based on. They emphasise the need to acknowledge notions of digital literacies and the need to recognise the affordances of social tools while also providing pedagogical initiatives that help foster these new kinds of literacies.

The current landscape of L2 writing is, therefore, one that is calling to go beyond a simple understanding of the writing system to one that is increasingly complex, multimodal, and becoming inextricably linked with the use of technology. However, as is common with a paradigm shift, there remains a need to maintain a connection to the traditional tenets of writing, particularly so with second language learners. For these learners, there is an obvious need to continuously work on foundational literacy in the form of the writing process, word recognition, vocabulary, comprehension, inferential reasoning, spelling, and responding to literature. However, while the use of technology affords learners opportunities to sharpen these, there is an equally obvious need for learners to have acquired some initial degree of technological literacy to get the best out of the tools and platforms being used.

The EHEA is one representative case of seeing the relationship between the 'old' foundational writing classroom and the 'new literacies' digital writing classroom in practice. The EHEA comprises international collaboration on higher education between 49 participating countries. Since the Bologna Process in 1999, there has been a concentrated effort from participating countries to collectively work on a set of common higher education goals.

EHEA goals include promoting student mobility, skills and employability, and maintaining comparability and transparency across its EHEA institutions' degree programmes (Pérez Cañado, 2013). Several 'Communiques' and 'Declarations' documents have set out the goals and advice on how to achieve them. A central theme is the focus on promoting student mobility and maximizing their ability to communicate in the international job market (Montero-Fleta \& Pérez-Sabater, 2010). Montero-Fleta and Sabater (2010) recognise the challenge of such international communication as it will more than likely require students to have competent written and spoken skills in English, given the status of English as an international lingua franca.

The Communiques and Declarations have provided advice on how institutions can develop a competency-based teaching framework that allows students to develop these ' $21^{\text {st }}$ century' international communication skills (e.g., Paris Communique, 2018). Pérez Cañado (2013) summarises that EHEA notions of competencies involve knowledge, skills, attitudes, and values. These notions enable students to perform successfully academically, professionally, and socially. Pérez Cañado (2018) further indicates how notions of competencies move towards a more student-centred model of learning where students become more autonomous and are capable of communicating across a range of modes and contexts. She pools together multiple characteristics of competencies to describe them as dynamic and in constant need of an update so they can be applied to different situations. Competencies are also viewed as transferable and observable and are therefore linked to a specific task and/or experience.

The role of technology and digitalisation in these frameworks is clarified by Rampelt et al. (2019) who highlight that digitalisation allows students to compete in the job market and partici- 
pate in a transformative society. This has led to many competency-based projects being implemented. Within these projects, the ability to write in English has a multifunctional role that is tied to technology. In one sense, technology draws out traditional foundational literacy; while in another sense, it also develops other competencies including new/digital literacies. In some projects, writing in English is seen as a generic competence that is 'cross-curricular', cutting across multiple degree programmes; and in others, it relates to a specific degree programme (Pérez Cañado, 2010).

These projects have involved using data-driven learning (e.g., Pérez Cañado \& Diez-Bedmar, 2006), digital storytelling (e.g., Papadopolou \& Vlachos, 2014), blogging (e.g., Montero-Fleta \& Pérez Sabater, 2010), games (e.g., Sanchez Perez \& Galera Masegosa, 2020) and telecollaboration activities (e.g., Sevilla-Pavón \& Haba-Osca, 2017) to, on one hand develop basic writing skills, but at the same time, develop technological, digitally focused literacies. This also contributes to the notion that EHEA institutions need to develop these literacies so as to produce citizens that are mobile and able to communicate globally.

However, despite these snapshots, a more complete EHEA picture is lacking in the literature. There is a need to systematically understand the extent that the teaching of writing reflects the paradigm shift being called for. Such an understanding would allow the writing classroom to be characterised in terms of the genres being taught and assessed, how an understanding of readership is being fostered and how writing under this digitalisation is evaluated and communicated to students. This paper, therefore, aims to describe the current landscape of how written literacy is shaped by the use of technology across the EHEA and to uncover the relationship between this foundational literacy and new literacies.

To this end, the systematic review is guided by the following research questions:

1. Across the body of EHEA literature, how is the notion of literacy characterised in terms of (a) the respective focus of instruction/assessment underpinning the research study, (b) the types of writing that students are asked to produce, (c) task types and considerations for the audience, $(\mathrm{d})$ the types of technology students are asked to use and (e) approaches taken to evaluate and provide feedback on students' literacy?

2. To what extent do these notions of literacy involve using technology to improve the traditional foundational literacies associate with writing either empirically or experientially?

3. To what extent are these notions of literacy also interconnected with the potential development of new literacies?

\section{The systematic review}

\subsection{The Data Collection Process}

The search focused on 15 international journals that serve the interests of the EHEA community. Google Scholar was also used to capture work published in local journals. The search included key terms such as CALL/MALL/ TELL and writing instruction in the EHEA AND Higher Education; Writing assessment and CALL/MALL/TELL in Higher Education in the EHEA; Learning about writing with technology in the EHEA as well as search terms for individual EHEA countries. Search terms were broad in nature so as to capture the EHEA landscape holistically and at the same time tap into each individual EHEA country.

From this initial search, an ancestry search was carried out from the reference lists of relevant studies, and the 'cited by' feature of Google Scholar was also used to trace forward advances since the publication of these original texts. Table 1 shows the breakdown of included studies per search activity. These numbers are after filtering duplicates and excluding irrelevant studies. When the search process reached a natural saturation point, and no new studies appeared, a final list of empirical studies was compiled. The search process resulted in a final study set of 33 studies. These studies appear with an asterisk $\left(^{*}\right)$ in the references section.

Table 1. Search Results

\begin{tabular}{|c|c|}
\hline Source & $\begin{array}{l}\text { Number } \\
\text { of Relevant } \\
\text { Studies }\end{array}$ \\
\hline Ancestry and cited by search & 11 \\
\hline Google Scholar & 7 \\
\hline Language Learning \& Technology (LL \& Tech) & 7 \\
\hline CALL & 2 \\
\hline Journal of Writing Research (JoWR) & 2 \\
\hline ReCALL & 2 \\
\hline Computers and Composition (C \& C) & 1 \\
\hline EuroCALL & 1 \\
\hline CALICO & 0 \\
\hline European Journal of Higher Education & 0 \\
\hline Higher Education in Europe & 0 \\
\hline Journal of Second Language Writing & 0 \\
\hline System & 0 \\
\hline Teaching English with Technology & 0 \\
\hline TESOL Quarterly & 0 \\
\hline Language Learning & 0 \\
\hline Written Communication & 0 \\
\hline
\end{tabular}

Studies in Table 1 were based on the following inclusion criteria:

- $\quad$ Studies had to be published between the years 2000 2020 to align with the original initiation of the Bologna Process in 1999; and the fruition of the EHEA in 2010.

- Studies had to have been peer reviewed to maximize their reliability.

- Studies had to be written in English and focus on English writing.

Several retrieved studies were excluded. Reasons for these exclusions varied, including their lack of explicit focus on writing (e.g., Sercu \& Peters, 2002), their focus on languages other than English (e.g., Strobl, 2014), or on high school students (e.g., Monje, 2014).

\subsection{Developing the Coding Scheme}

After obtaining this final list, each study was coded for features developed in the coding scheme shown in Table 2. The coding scheme was developed so as to set out the contextual landscape of the studies as well as to document specific information relating to the writing types and tasks and readership, and the digital tools used in each study. 
Table 2. Coding Scheme for Studies

\begin{tabular}{|c|l|}
\hline \multicolumn{2}{|c|}{ Study Coding } \\
\hline ID & $\begin{array}{l}\text { Year, Author; Journal; Article Title + Full biblio- } \\
\text { graphic reference. }\end{array}$ \\
\hline Sample & $\begin{array}{l}\text { Sample size; details about student/teacher } \\
\text { groups (e.g., age; gender; proficiency level; pro- } \\
\text { ficiency level judgements). }\end{array}$ \\
\hline Context & $\begin{array}{l}\text { Teacher and researcher's role on course; course } \\
\text { information. }\end{array}$ \\
\hline $\begin{array}{c}\text { Writing } \\
\text { Details }\end{array}$ & $\begin{array}{l}\text { Genre; readership/audience; evaluation of task } \\
\text { completion; focus of writing proficiency. }\end{array}$ \\
\hline $\begin{array}{c}\text { Treatment } \\
\text { Intervention }\end{array}$ & $\begin{array}{l}\text { \# groups; target writing features; intervention } \\
\text { type; length of intervention; intensity of instruc- } \\
\text { tion/intervention; training. }\end{array}$ \\
\hline $\begin{array}{c}\text { Recording } \\
\text { literacies }\end{array}$ & $\begin{array}{l}\text { Types of literacies that interact with foundational } \\
\text { literacies (e.g., computer literacy). }\end{array}$ \\
\hline
\end{tabular}

To check the coding consistency, a second coder was employed to code a small sample of the study set (10 studies). Discussions with the second coder clarified any points of contention and suggested revisions and additions to the coding. After this, the 23 remaining studies were coded.

\section{Results and discussion}

\subsection{Characteristics of EHEA Studies and Writing Classrooms}

The search process yielded studies from a few of the 49 EHEA countries. Figure 1 shows most studies occurred between 2010 - 2020. This trend may reflect increased efforts of EHEA countries to follow EHEA goals and/or reflect the general trend of using technology in the writing classroom. Figure 2 highlights that most studies took place in Turkey $(n=14)$, followed by Spain $(n=10)$, and then more fragmented scatterings of studies across mixed EHEA countries. These patterns may be because Turkey, Spain, and Italy have implemented technology-focused reform projects (e.g., see Turkey's FATiH project (2021). Another feature of the landscape is uncovered by studying the publication venue. Figure 3 reveals that the preference for publication is not necessarily in a technology-focused journal. Most studies were retrieved using ancestry/cited by searches and Google Scholar. These studies were published in local and international journals (e.g., 'Bartm University Journal of Faculty of Education'; 'International Online Journal of Educational Sciences'). The search retrieved fewer studies in specific technology/CALL journals (e.g., few studies were retrieved from 'EUROCALL', 'CALL', and 'ReCALL').

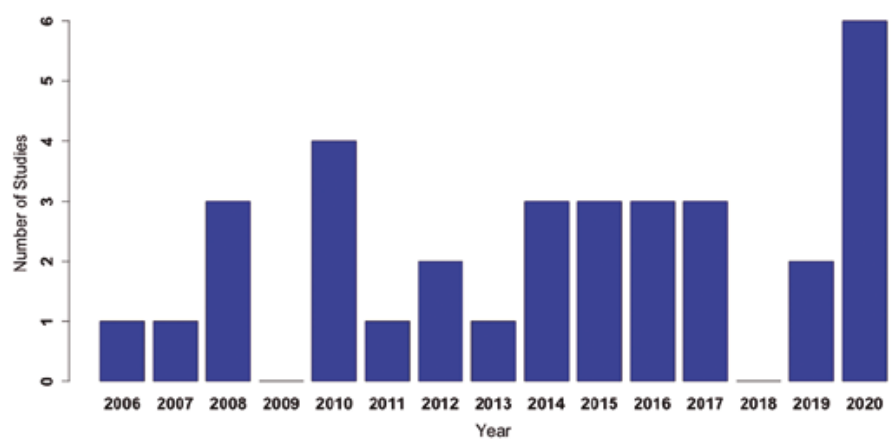

Figure 1. Study Breakdown per Year

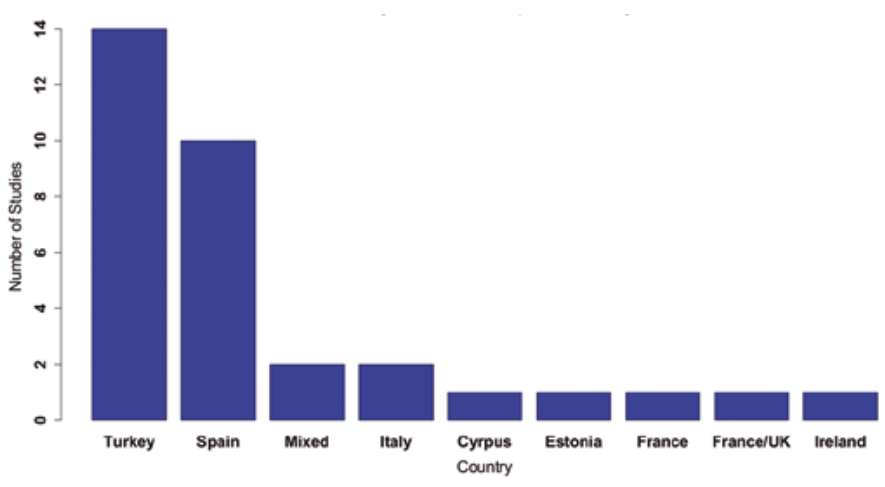

Figure 2. Study Breakdown per Country

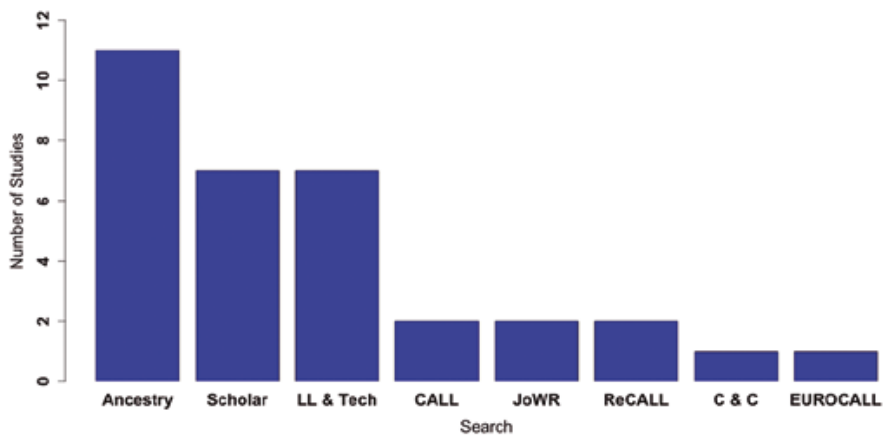

Figure 3. Study Breakdown per Search Activity

The majority of studies concerned EAP undergraduate courses, although some studies focused on ESP (e.g., Leijen, 2017). The following sections describe trends in investigations, the types of writing and audience highlighted, the types of technologies used, the tasks that students are given, and how writing is evaluated.

\subsubsection{Study Focus}

Studies generally followed two tracks: investigating the effect of an intervention on features of writing or looking at how types of online feedback influence student revisions or perceptions of the writing process. There was an overwhelming focus on improving linguistic features and/or a particular component of writing proficiency that was deemed appropriate to the students/ teaching context. This focus was also evident in the evaluation criteria being used.

Most studies did not draw on a specific theoretical framework $(n=22)$. Some grounded their work in the perceived benefits of technology or their particular tool of choice. Studies that did draw on a framework tended to draw on similar frameworks. Vygotsky's (1978) Zone of Proximal Development (ZPD) and/ or sociocultural theories of learning were popular anchors for authors $(n=4)$. Other studies drew on Genre Theory (e.g., Lirola \& Cuevas, 2008) and/or constructivist theories of learning (e.g., Luna et al., 2020).

Where student writing was the explicit focus, most studies provided details of the number of students taking part and their demographic profiles. Studies included on average, 56 students, whose ages ranged from 17 to 36 and over, with more female students involved. Eight studies did not report the English language proficiency level of the students. The remaining studies contained students with false beginner to advanced proficiency 
levels, or were reported according to CEFR (Common European Framework of Reference) levels (e.g., ranging from CEFR A2-B2) (Council of Europe, 2009). Methods of judging proficiency levels were often unreported. Studies that did report their judgements, used placement tests (e.g., Arslan \& Sahin-Kizil, 2010) or relied on students' self-ratings of their general English or writing proficiency (e.g., Tavalán et al., 2016).

\subsubsection{Types of Technology, Writing, and Tasks}

Studies varied in the technology used, the genres produced, and the tasks completed. Overall, studies promoted multiple types of technology such as bespoke and commercial software, blogs, wikis, subtitling, e-portfolios, and comprehensive uses of Learning Management Systems (LMSs).

Researchers followed two approaches: one using technology to improve students' production of a particular genre or improve a particular linguistic feature; and the other using technology in an integrated way to document the effects of the technology on a range of language skills (including writing). Under these approaches, students produced various genres including different essays (e.g., argumentative, descriptive, expository, comparison and contrast, and reflection), letters, and emails.

Students also completed various tasks. In some effect-based studies, students were randomly split into experimental and control groups. In these studies, the technology or task type was used as an experimental intervention, and its effect on the written product was measured statistically (e.g., Arslan \& Sahin-Kizil, 2010). Figure 4 shows the general trends of technology use in these studies.

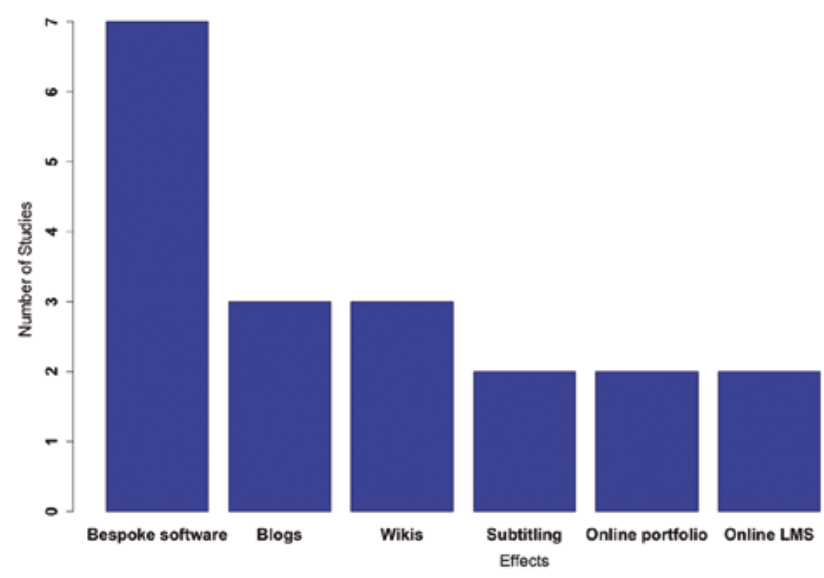

Figure 4. Effect Studies

Figure 4 shows that many effect studies used different types of bespoke and commercial software. This software included a focus on data-driven learning corpus-based tasks (e.g., Pérez Cañado \& Diez-Bedmar, 2006; Ackerely, 2017). In an interesting use of data-driven activities, Ackerely (2017) focused on the effects of data-driven language activities on students' use of phraseology. In her sample of 223 first-year students in Italy, she found that students who completed the data-driven activities used more genre-appropriate phraseology and less stock phrases when compared with the group who worked with paper-based exercises.

A different focus was taken by MacDonald et al. (2013) and Lawley (2015) who used software to tackle students' self-correction of errors. Focusing on Lawley (2015), he trialled a bespoke word combination error correction tool with Spanish university students. The tool allowed students to self-correct word combinations that may be flagged up as unusual and/or erroneous. Students reported that the tool helped them identify and correct errors quickly. They also reported on the tool's discussion forum that the tool allowed them to reflect on erroneous combinations.

Other studies followed unique approaches, with two of these studies offering insights into particular genres. Benetos and Betrancourt (2020) studied the effect of the software 'C-SAW' on students' argumentative writing in a Spanish university. They looked at the number and completion of arguments in terms of presenting claims, counter arguments, and responses. They found that participants writing with 'C-SAW' overall elaborated more on arguments, but there were no other significant differences between the 'C-SAW' group and the control group. Lirola and Cuevas (2008) carried out a two-year study in Spain. They used error correction software and instructed students to use the error information to correct their texts. However, after one year, they found that students had failed to properly act on the error information. They then introduced sessions aligning with genre theory into their teaching. These sessions aimed to teach students to use genre-appropriate language. They found after year two that texts contained more transitions and more illustrations, and therefore, the dual use of correction software and genre theory input was deemed to have a positive effect on students' texts.

Coşkun and Ghaemi (2015) reported the influence of the 'Net Support' platform on general self-regulation and writing development in Turkish students' writing. They set multiple tasks on Net Support including self-assessment, and they also relied on stronger students to support their weaker counterparts. They found that students' TOEFL writing scores increased from the pre and post-test. However, these increases do not appear to be statistically significant. In a different focus, Yüce's (2020) study presented the diary software 'Penzu' to teachers to gather their thoughts on the diary's potential use in a Turkish university. Instructors commented that the diary might improve students' fluency, but since there was no onus on providing feedback, improvements may be limited.

A few studies in Turkey and Spain $(n=3)$ looked at the effects of blogs (Arslan \& Sahin-Kizil, 2010; Montero-Fleta \& Pérez-Sabater, 2010; Kazanci \& Caser, 2020). Overall, studies showed that blogs improved written texts, students found them beneficial, and they made students more aware of the importance of audience. A few studies in Turkey and Spain $(n=2)$ looked at the effects of wikis. In Turkey with advanced level students, Celik and Aydin (2016) found that wikis improved students' content scores between the pre and post-tests when students completed TOEFL tasks. In Spain, Montero-Fleta and Perez Sabater (2014) used wikis to allow students to create a class grammar textbook. The textbook included different grammar points explained by the students. They reported that the use of wikis improved students' linguistic skills.

Two studies on using e-portfolios in Turkey produced mixed results. When students were asked to produce portfolios on a number of personal topics, Baturaya and Daloglu (2010) found that, although the e-portfolio group increased their writing scores, the non-e-portfolio group also increased their writing scores from the pre to post-tests. They note that there were no significant differences between the groups' scores. In a later study, Baturay (2015) tapped into student perceptions of how the use of e-portfolios impacted their attitude towards writing and the perceived gains they made in developing their texts. Students felt that the portfolios improved their vocabulary and grammar, allowed them to see their mistakes, and increased their motivation to write. 
Tavalán et al. (2016) and Tavalán et al. (2019) looked at the effect of subtitling on writing literacy in Italy and Spain. Their work provides a clear insight into how the multimodal activity of providing subtitles on a film/TV series can have positive effects on writing. They reported that students improved their coherence, cohesion, and idea structuring but made fewer improvements in spelling, register, and style.

The final two software studies used multiple features in their respective LMSs. Luna et al. (2020) designed a training programme for Spanish students to improve their argumentative writing. Students had to complete around 45 minutes of online activities and post-reflection tasks to Padlet. The activities aimed to improve the number and integration of arguments. The online training group improved the number of arguments for and against the position and the degree of integration of the two perspectives. Ekmecki (2017) looked at the effect of a flipped classroom on students' writing improvement in Turkey. Students were split into experimental and control groups, where the experimental group experienced the flipped environment while the control group experienced traditional lectures. The experimental group was found to have increased their writing scores at the end of the teaching period.

Some studies provided holistic accounts of how they remodelled their course learning outcomes and learning activities in line with EHEA developments (e.g., Pérez Cañado, 2010; Zaragoza Ninet \& Arroitia, 2008). For other scholars, their focus on redevelopment was not explicitly linked to the EHEA, but they continued to emphasise the move towards more student-centred digital learning (e.g., Murray et al., 2007; Ciekanski \& Chanier, 2008). These studies did not focus on more statistically-evidenced gains as those studies in Figure 4, but instead provided descriptive accounts of the impact of technology more broadly. Among these accounts, Ciekanski and Chanier (2008) drew on multimodal theories to track how students responded to a multimodal learning environment when producing collaborative writing in French and UK institutions. In sum, they tracked students' use of multimodal text, audio, and word processing software and found the multimodal environment helped students focus more on the process of writing rather than the text product produced at the end.

Turning to studies that used technology to provide feedback, Figure 5 shows a range of feedback types and tools.

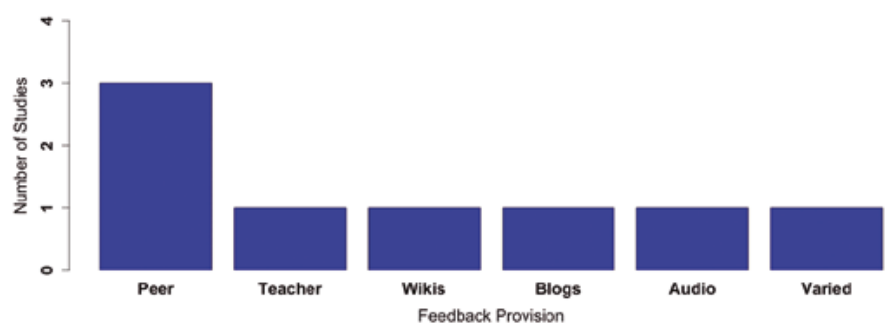

Figure 5. Feedback Studies

Peer feedback studies adopted different approaches (Ciftci \& Kocoglu, 2012; Pérez Paredes \& Diez Bedmar, 2012; Leijen, 2017). Taken together, these studies show that peer feedback via blogging helped students improve their writing scores (Ciftci \& Kocoglu, 2012) and that the platform in terms of the type of feedback that students respond to is also important (Pérez Paredes \& Diez Bedmar, 2012; Leijen, 2017).

Teacher-provided feedback was less common. Sarré et al. (2019) studied how various types of online corrective feedback being used with English language writers in France could improve accuracy. Feedback included direct and indirect types with computer-mediated tasks. Overall, they found that any type of corrective feedback was better than none and that the repeated provision of unfocused indirect corrective feedback (with metalinguistic comments on the nature of errors) combined with extra computer-mediated micro-tasks was the most efficient type of corrective feedback.

Other studies focused on providing feedback through wikis, blogs, audio, and a mixture of different modes (Arslan, 2014; Aydin \& Yildiz, 2014; Bakla, 2020; Kleanthous \& Cardoso, 2016; Solhi \& Eginli, 2020). On the whole, studies show mixed results for how feedback impacts writing literacy. Arslan's (2014) study of Turkish students blogging and receiving peer and teacher feedback found improvements in content, organisation, vocabulary, grammar, and mechanics scores; however, with studies on the role of audio and other types of feedback, the picture is less clear.

Studying audio feedback, Solhi and Eginli (2020) found significant differences between experimental and control groups with the experimental group improving their content and organisation scores more, but no statistically significant differences were found between the groups for mechanics, clarity, or sentence level accuracy. Bakla's (2020) study of written, audio and screencast feedback also presents a mixed picture with audio feedback leading to the correct revisions when students completed a writing revision task; however, when producing their own written essays, there were no significant differences between feedback types. Aydin and Yildiz's (2014) study looked at the self and peer correction patterns of Turkish students across wiki-based tasks. They found that there was a greater focus on meaning-making changes over form changes and that in both cases, the accuracy of these changes was high. In Cyprus, Kleanthous and Cardoso (2016) examined the effects of peer feedback and blogging on writing improvements on an ESP course. They found that both endeavours improved students writing with mistakes from the first essays not repeated in later writing. They also found that students had a positive attitude towards providing feedback. During feedback, Kleanthous and Cardoso (2016) noted that the students tend to focus on global levels of writing such as the format and style of the texts as opposed to more local linguistic levels such as spelling and mechanics.

\subsubsection{Audience}

Although studies were rich in writing genre, task, and technology use, there was little evidence of promoting a range of readerships for the work being produced. Many effect studies showed little evidence of encouraging students to consider readership; when the audience was more clearly stated, it tended to be geared towards class peers and/or the instructor. There were isolated studies that acknowledged the importance of audience through getting students to produce texts such as a grammar textbook where communication was at an individual and group reader level (e.g., Montero-Fleta \& Pérez Sabater, 2014).

This pattern was also apparent in feedback studies. These generally promoted teacher and peer readership; however, only a few studies mentioned wider readership in the form of students at different institutions and family members (e.g., Arslan \& Sahin-Kizil, 2010).

\subsubsection{Targeted Areas of Writing and Evaluation}

Studies relied on standardised analytical and/or holistic rubrics with some of these rubrics adapted from commonly used 
ELT rubrics (e.g., the ESL Composition Scale from Hughey et al., 1983). These rubrics contained a narrow range of constructs that were deemed to be measures of writing quality and/or areas of weakness in student writing that the technological intervention aimed to improve. Accuracy was an overwhelming feature of writing improvement and/or evaluation with most studies focusing on an aspect of accuracy (e.g., broad aspects of grammar, tense forms, articles, mechanics). However, there were individual studies that tapped into more 'formulaic' ways of writing by instructing students how many paragraphs to write, the need for a thesis statement, a hook, an introduction, and conclusion and generally adopted a step-by-step, itemized approach in their rubrics (e.g., Bakla, 2020). Other studies evaluated writing under global and local aspects. Global aspects related to logic/supporting details, level of argument, organisation, the inclusion of a thesis statement; while local aspects included aspects of style, writing conventions, paraphrasing, and vocabulary use (e.g., Leijen, 2017).

\subsection{The Development of Foundational Literacies}

Overall, studies provide ample evidence that the use of technology leads to improvements in empirical or experiential writing gains. A striking feature of studies is their focus on developing foundational literacies that capture traditional linguistic feature use and considerations for linguistic accuracy, fluency, and local aspects of text production, with less attention paid to aspects of genre and readership.

The development of foundational literacies is also evident from examining the rubrics used to evaluate texts. Overall, the reviewed literature signals two important points. The first is that technology is being used to tap into features associated with a traditional writing classroom (i.e., producing a single written text for a single reader). The second point is that there is a lack of authentic writing that accurately reflects the types of writing students are expected or will be expected to produce in their later academic and/or professional lives, presumably as they become the mobile, global citizens that the EHEA aims to produce.

However, although these patterns emerge from the studies themselves, it is imperative to consider this landscape in context. The use of technology in these classrooms is for many instructors, students, and programme faculty/leaders, a substantial change from their previous experiences of a teacher-centred classroom. This difference needs to be considered when making calls to promote 'new' literacies and a ' $21^{\text {st }}$-century' writing classroom.

\subsection{The Development of New Literacies}

In the majority of studies, there were training sessions or stepby-step support provided by instructors. Teachers often acted as consultants and answered technical problems, and monitored task completion online (e.g., Ciekanski \& Chanier, 2008). Teachers also led training sessions in data-driven learning activities whilst acknowledging that this training was crucial to students' success in activities (e.g., Ackerely, 2017), as well as training in specific error correction software (e.g., Lawley, 2015).

However, there was little acknowledgement that students' development or existing levels of 'new literacies' may play a mediating role in how foundational writing literacies develop. More than half of the 33 studies did not refer directly to the influence of existing or developing-in-tandem influence of new technology-focused literacies. Some studies acknowledged that students' computer literacy may have influenced their performance (e.g., Arslan \& Sahin-Kizil, 2014) and that students had the experience of social interaction on the internet (sending emails and instant messaging) but little experience of technology use in education (e.g., Aydin \& Yildiz, 2014).

\section{Conclusion}

This overview has highlighted many trends. The systematic review has drawn out patterns of similarity and difference across contexts. While this landscape is moving towards a digitally informed classroom, there are many uses of technology and aspects of literacy that remain unexplored. The majority of studies focus on foundational literacy with few studies focusing on multimodality. There are few examples of the kinds of studies promoted by Nation and Macalister (2021), where students experience writing multiple genres for multiple audiences. However, while these studies would be welcome, for many individual contexts, the underlying gist of their existing research studies is one of student struggle in EFL writing. There is a clear impression from studies that students struggle to communicate in basic written form, and so suggestions to introduce more multimodal, multimedia activities should be treated with caution.

\section{References}

References marked with an asterisk $\left({ }^{*}\right)$ indicate studies included in this review.

*Ackerely, K. (2017). Effects of corpus-based instruction on phraseology in learner English. Language Learning and Technology, 21(3), 195-216. http://llt.msu.edu/issues/october2017/ackerley. pdf

*Arslan, R. Ş., \& Şahin-Kızıl, A. (2010). How can the use of blog software facilitate the writing process of English language learners? Computer Assisted Language Learning, 23(3), 183-197. https://doi.org/10.1080/09588221.2010.486575

*Arslan, R. Ş. (2014). Integrating feedback into prospective English language teachers' writing process via blogs and portfolios. The Turkish Online Journal of Educational Technology, 13(1), 131150. http://www.tojet.net/articles/v13i1/13112.pdf

*Aydin, Z., \& Yildiz, S. (2014). Using Wikis to promote collaborative EFL writing. Language Learning and Technology, 18(1), 160180. http://llt.msu.edu/issues/february2014/aydinyildiz.pdf

*Bakla, A. (2020). A mixed-methods study of feedback modes in EFL writing. Language Learning and Technology, 24(1), 107-128. https://doi.org/10125/44712

*Baturay, M. H. (2015). Online English language learners' perceptions of portfolio assessment. Teaching English with Technology, 15(4), 16-28.

*Baturaya, M. H., \& Daloglu, A. (2010). E-portfolio assessment in an online English language course. Computer Assisted Language Learning, 23(5), 413-428. https://doi.org/10.1080/09588221.201 0.520671

*Benetos, K., \& Betrancourt, M. (2020). Digital authoring support for argumentative writing: What does it change? Journal of Writing Research, 2(1), 263-290. https://doi.org/10.17239/jowr2020.12.01.09

*Celik, S. S., \& Aydin, S. (2016). Wiki effect on English as a foreign language writing achievement. Global Journal of Foreign Language Teaching, 6(4), 218-227. https://doi.org/10.18844/gjflt. v6i4.1674

Cervetti, G., Damico, J., \& Pearson, P. D. (2006). Multiple literacies, new literacies, and teacher education. Theory Into Practice, 45(4), 378-386. https://doi.org/10.1207/s15430421tip4504_12

*Ciekanski, M., \& Chanier, T. (2008). Developing online multimodal verbal communication to enhance the writing process in 
an audio-graphic conferencing environment. ReCALL, 20(2), 162-182

${ }^{*}$ Ciftci, H., \& Kocoglu, Z. (2012). Effects of peer e-feedback on Turkish EFL students' writing performance. Journal of Educational Computing Research, 46(1), 61-84. https://doi.org/10.2190/ EC.46.1.c

*Coşkun, A., \& Ghaemi, H. (2015). Integrating technologically-enhanced self-regulated strategies into writing English as a foreign language classes. International Online Journal of Educational Sciences, 7(2), 1-14. http://dx.doi.org/10.15345/iojes.2015.02.006

Council of Europe. (2009). Manual for relating language examinations to the common European framework of reference for languages: Learning, teaching, assessment. https://biblio.ugent.be/publication/4270320/file/4270333

*Diez Bedmar, M. B., \& Pérez Paredes, P. (2012). The types and effects of peer native speakers' feedback on CMC. Language Learning and Technology, 16(1), 62-90. http://llt.msu.edu/issues/ february2012/diezbedmarperezparedes.pdf

*Ekmekci, E. (2017). The flipped writing classroom in Turkish EFL context: A comparative study on a new model. Turkish Online Journal of Distance Education, 18(2), 151-167

Elola, I., \& Oskoz, A. (2017). Writing with $21^{\text {st }}$ century social tools in the L2 classroom: New literacies, genres and writing practices. Journal of Second Language Writing, 36, 52-60. https://doi. org/10.1016/j.jslw.2017.04.002

FATiH Project. (2021). FATiH Project Information. http://fatihprojesi.meb.gov.tr/en/index.html

Godwin-Jones, R. (2018). Second language writing online: An update. Language Learning and Technology, 22(1), 1-15. https:// dx.doi.org/10125/44574

Hafner, C. (2014). Embedding digital literacies in English language teaching: Students' digital video projects as multimodal ensembles. TESOL Quarterly, 48, 655-68. https://doi.org/10.1002/ tesq. 138

Hughey, J. B., Wormuth, D. R., Hartfiel, v. F., \& Jacobs, H. L. (1983). Teaching ESL composition: Principles and techniques. Newbury House.

*Kazanci, R., \& Caner, M. (2020). Weblogs in EFL writing course. Journal of Narrative and Language Studies, 8(14), 152-163

*Kleanthous, A., \& Cardoso, W. (2016). Collaboration through blogging: the development of writing and speaking skills in ESP courses. In S. Papadima-Sophocleous, L. Bradley \& S. Thouësny (Eds.), CALL communities and culture - short papers from EUROCALL 2016 (pp. 225-229). Research-publishing.net.

Knobel, M., \& Lankshear, C. (2018). Language teachers researching and understanding new literacies and language-in-use from a social languages perspective. The European Journal of Applied Linguistics and TEFL, 8(2), 159-174.

*Lawley, J. (2015). New software to help EFL students self-correct their writing. Language Learning and Technology, 16(1), 62-90. http://llt.msu.edu/issues/february2015/action1.pdf

*Leijen, D. A. J. (2017). A novel approach to examine the impact of web-based peer review on the revisions of L2 writers. Computers and Composition, 43, 35-54. https://doi.org/10.1016/j.compcom.2016.11.005

Leu, D. J., Kinzer, C. K., Corio, J., Casek, J., \& Henry, L. A. (2013). New literacies: A dual level theory of the changing nature of literacy, instruction and assessment. In D. E. Alvermann, N. J. Unrau, \& R. B. Ruddell (Eds.), Theoretical models and processes of reading (pp. 1150-1181). International Reading Association.

*Lirola, M. M., \& Cuevas, M. T. (2008). Integrating CALL and genre theory: A proposal to increase students' literacy. ReCALL 20(1), 67-81. https://doi.org/10.1017/S095834400800061X
*Luna, M., Villalón, R., Mateous, M., \& Martin, E. (2020). Improving university argumentative writing through online training. Journal of Writing Research, 12(1), 233-262.

*MacDonald, P., Garcia-Carbonell, A., \& Carot-Sierra, J. M. (2013). Computer learner corpora: Analysing interlanguage errors in synchronous and asynchronous communication. Language Learning and Technology, 17(2), 36-56. http://llt.msu.edu/issues/ june2013/macdonaldetal.pdf

Monje, E. M. (2014). Integration of Web 2.0 tools in a VLE to improve the EFL Spanish university entrance examination results: A quasi-experimental study. CALICO Journal, 31(1), 40-56. https://doi.org/10.1558/cj.31.1.40-56

*Montero-Fleta, B., \& Pérez-Sabater, C. (2010). A research on blogging as a platform to enhance language skills. Procedia-Social and Behavioral Sciences, 2, 773-777. https://doi.org/10.1016/j.sbspro.2010.03.100

*Montero-Fleta, B., \& Pérez-Sabater, C. (2014). Analysing the myth of digital natives in an English course: A higher education collaborative approach. LSP Journal, 5(2), 24-43.

*Murray, L., Hourigan, T., \& Jeanneau, C. (2007). Blog writing integration for academic language learning purposes: Towards an assessment framework. Ibérica, 14, 9-32.http://www.redalyc.org/articulo.oa?id=287024055002

Nation, I. S. P., \& Macalister, J. (2021). Teaching ESL/EFL reading and writing ( $2^{\text {nd }}$ ed.). Routledge.

*Ozkan, Y. (2011). Blogging in a teaching skills course for pre-service teachers of English as a second language. Australian Journal of Educational Technology, 27(4), 655-670. https://doi. org/10.14742/ajet.943

Paris Communiqué. (2018). The EHEA Ministerial Conference. https://www.diplomatie.gouv.fr/en/french-foreign-policy/europe/news/article/european-higher-education-area-ehea-ministerial-conference-paris-communique-25

Papadopolou, S., \& Vlachos, K. (2014). Using digital storytelling to develop foundational and new literacies. Research Papers in Language Teaching and Learning, 5(1), 235-258.

*Pérez Cañado, M. L., \& Diez Bedmar, M. B. (2006). Data-driven learning and awareness-raising: An effective tandem to improve grammar in written composition? iJET: International Journal of Emerging Technologies in Learning, 1(1), 1-11. https:// online-journals.org/index.php/i-jet/article/view/55/37

*Pérez Cañado, M. L. (2010). English language teaching in the EHEA: From policy to practice. Innovation in Language Learning and Teaching, 4(1), 53-69. https://doi. org/10.1080/17501220902842998

Pérez Cañado, M. L. (2013). The development of ICT competence within Bologna-adapted language degrees. The International HETL Review. https://www.hetl.org/2013/page/36/

Pérez Cañado, M. L. (2018). Technology for teaching English as a Foreign Language (EFL) writing. In G. Kessler (Ed.), The TESOL Encyclopedia of ELT (pp. 1-12). Wiley. https://doi. org/10.1002/9781118784235.eelt0439

Rampelt, F., Orr, D., \& Knoth, A. (2019). Bologna Digital 2020 White paper on digitalisation in the European Higher Education area. Hochschulforum Digitalisierung. https://hochschulforumdigitalisierung.de/sites/default/files/dateien/2019-05_ White_Paper_Bologna_Digital_2020_0.pdf

Sanchez Perez, M. D. M., \& Galera Masegosa, A. (2020). Gamification as a teaching resource for English Medium Instruction and multilingual education at university. In A. Andujar (Ed.), Recent tools for computer and mobile-assisted foreign language learning (pp. 248-267). IGI Global.

*Sarré, C., Grosbois, M., \& Brudermann, C. (2019). Fostering accuracy in L2 writing: Impact of different types of corrective 
feedback in an experimental blended learning EFL course. Computer Assisted Language Learning. https://doi.org/10.1080 /09588221.2019.1635164

Sercu, L., \& Peters, E. (2002). Learning e-learning - a comprehensive investigation of course developers' and language teacher trainees' views regarding the usefulness and effectiveness of a multimedia self-tuition course. ReCALL, 14 (1), 32-46. https:// doi.org/10.1017/S0958344002000411

Sevilla-Pavon, A., \& Haba-Osca, J. (2017). Learning from real-life and not books: A gamified approach to business English task design in transatlantic telecollaboration. Iberica, 33, 235-260 http://www.redalyc.org/articulo.oa?id=287050576010

*Solhi, M., \& Eğinil, I. (2020). The effect of recorded oral feedback on EFL learners' writing. Journal of Language and Linguistic Studies, 16(1), 1-13.

Strobl, C. (2014). Affordances of Web 2.0 technologies for collaborative advanced writing in a foreign language. CALICO Journal, 31(1), 1-18.
*Tavalán, N., Ibanez, A., \& Bárcena, E. (2016). Exploring collaborative reverse subtitling for the enhancement of written production activities in English as a second language. ReCALL, 29(1), 39-58. https://doi.org/10.1017/S0958344016000197

*Tavalán, N., Lertola, J., \& Costal, T. (2019). iCap: Intraligual captioning for writing and vocabulary enhancement. Alicante Journal of English Studies, 29, 229-248. https://doi.org/10.14198/ raei.2016.29.13

Vygotsky, L. (1978). Mind in society. Harvard University Press.

*Yüce, E. (2020). Keeping online diary as an integrated activity for developing writing skill in EFL classes through Penzu. Bartm University Journal of Faculty of Education, 9(1), 132-140.

Zaragoza Ninet, M. G., \& Arrotia, B. C. (2008). ICT implementation in English language and English dialectology. GRETA, 16(1\&2), 78-84. 
